\title{
Green Synthesized Nanomaterials: An Analysis of the Impact on Cellular Processes, Gene Regulation, and Epigenome
}

\author{
Nisha Khatik \\ Department of Botany, Maharshi Dayanand Saraswati University, Ajmer- 305009, Rajasthan, India
}

Received May 27, 2021; Revised August 18, 2021; Accepted October 17, 2021

\section{Cite This Paper in the following Citation Styles}

(a): [1] Nisha Khatik, "Green Synthesized Nanomaterials: An Analysis of the Impact on Cellular Processes, Gene Regulation, and Epigenome," International Journal of Biochemistry and Biophysics, Vol. 9, No. 2, pp. 17 - 26, 2021. DOI: 10.13189/ijbb.2021.090201.

(b): Nisha Khatik (2021). Green Synthesized Nanomaterials: An Analysis of the Impact on Cellular Processes, Gene Regulation, and Epigenome. International Journal of Biochemistry and Biophysics, 9(2), 17 - 26. DOI: 10.13189/ijbb.2021.090201.

Copyright $\subseteq 2021$ by authors, all rights reserved. Authors agree that this article remains permanently open access under the terms of the Creative Commons Attribution License 4.0 International License

\begin{abstract}
Green synthesis of nanoparticles has gained prominence in recent years as a cost-effective and environmentally sustainable approach. This green nanotechnology has diverse applications, and their potential impact on cellular processes needs to be thoroughly examined via nanomaterials. One of the major challenges in this field is the alleviation of oxidative damage, cytotoxicity, and genotoxicity induced by nanoparticles. Lately, research is more focused on analyzing the epigenetic effects including DNA methylation and histone modifications mediated through the alteration in microRNA expression that is influenced by nanoparticles. Due to their physical and chemical properties, these nanomaterials are extremely suitable carriers of targeted modifications in gene regulatory systems. Delivery of silencing RNAs and artificial transcription factors built on nanoparticles for modulating gene expression has been extensively reported in recent years. Studies on various cell lines have confirmed the downstream effects of these changes in gene expression, as demonstrated by the significant alteration in expression of proteins functional in a multitude of pathways, such as those associated with oxidative stress, cytoskeletal proteins, molecular chaperones, proteins involved in energy metabolic processes, and apoptosis and tumor-related proteins. This reshuffling of molecular expression has also been corroborated by investigations at genomic, transcriptomic, proteomic, and metabolomic levels. This
\end{abstract}

chapter highlights the detailed mechanism of modulation of gene regulation and expression, and the cytological and molecular changes caused by these bionanomaterials. The toxicological aspects and biocompatibility impacts of these nanoparticles, which are of paramount importance while considering their biomedical and environmental applications, have also been outlined.

Keywords Nanoparticles, Green Synthesis, Gene Regulation, Gene Expression, MicroRNAs

\section{Introduction}

Nanoscience and technology has steadily gained ground over the past decade due to its application in diverse fields such as biomedical and health sector, food and feed industry, drug-gene delivery system, chemical industry, electronic industry, space research, optical devices, environmental remediation, and many more such uses. The conventional method of synthesis of these nanoparticles (NPs) has been through either the top down approach (where larger structures are broken down into fine particles of suitable size using physical, chemical or thermal techniques) or through the bottom up method (where NPs are assembled from simpler atoms and molecules). However, utilization of these NPs is limited 
by factors like lack of stability in antagonistic environment, concerns regarding bioaccumulation and toxicity, need of highly trained workers for device assembly and operation, and problems with reproducibility and affordability [1].

Advancement over these techniques has been made possible by the emergence of green synthesis of NPs, which is more time-consuming, but is relatively eco-friendly, reproducible, cost-effective and more stable. A variety of organisms including microbes such as viruses, bacteria, algae and fungi and plants, and biologically synthesized compounds like honey, have been employed for the synthesis of these biogenic NPs [2,3]. Green synthesis complies with the bottom up approach, where biological reductants like enzymes and phytochemicals are utilized for the reduction of metal complexes to their respective NPs [4].

\section{Cellular Effects of Green Nanoparticles}

Depending on their size, shape and other bioactivity characteristics, NPs are able to enter cells and translocate through cells, tissues and organs by various active as well as passive uptake mechanisms, and affect various cellular reactions [5]. The surface charge of NPs is an important factor in deciding the specific cellular receptors activated, which in turn regulates the cytotoxicity associated with it. Many studies have highlighted the impact of chemically synthesized NPs on various cellular processes, but issues concerning green synthesized NPs need to be assessed comprehensively. A brief summary of the reported effects of green synthesized NPs has been consolidated below and listed in Table 1.

Table 1. Documented effects of green synthesized nanomaterials

\begin{tabular}{|c|c|c|c|c|}
\hline Type of NPs & $\begin{array}{l}\text { Organism used for } \\
\text { synthesis }\end{array}$ & $\begin{array}{c}\text { Organisms/cell lines } \\
\text { that were subjected to } \\
\text { the NPs }\end{array}$ & Effects documented & References \\
\hline \multirow{13}{*}{$\begin{array}{l}\text { Silver NPs } \\
\text { (AgNPs) }\end{array}$} & \multirow{4}{*}{$\begin{array}{l}\text { Atropa acuminata leaf } \\
\text { extract }\end{array}$} & $\begin{array}{l}3^{\text {rd }} \text { instar larvae of } \\
\text { mosquitoes Anopheles } \\
\text { stephensi, Aedesaegypti, } \\
\text { and Culex } \\
\text { quinquefasciatus }\end{array}$ & Larvicidal activity & \multirow{4}{*}{$\begin{array}{l}\text { Rajput et } \\
\text { al. } 2020[6]\end{array}$} \\
\hline & & $\begin{array}{l}\text { Human cervical cancer } \\
\text { cell line HeLa }\end{array}$ & Cytotoxicity & \\
\hline & & $\begin{array}{l}\text { Human embryonic } \\
\text { kidney cell line HEK } 293\end{array}$ & No toxicity & \\
\hline & & In vitro assay & $\begin{array}{l}\text { Free radical scavenging activity, } \\
\text { inhibition of albumin denaturation, and } \\
\text { antiprotease activity }\end{array}$ & \\
\hline & Beta vulgaris root extract & $\begin{array}{l}\text { Human hepatic normal } \\
\text { (CHANG) and cancer } \\
\text { (HuH-7) cell lines }\end{array}$ & $\begin{array}{l}\text { Loss of mitochondrial membrane } \\
\text { potential, induction of apoptosis, DNA } \\
\text { damage }\end{array}$ & $\begin{array}{l}\text { Bin-Jumah } \\
\text { et al. } 2020 \\
\text { [17] }\end{array}$ \\
\hline & $\begin{array}{l}\text { Salvia officinalis leaf } \\
\text { extract }\end{array}$ & $\begin{array}{l}\text { Human breast cancer cell } \\
\text { line MCF-7 }\end{array}$ & Proinflammatory activity & $\begin{array}{l}\text { Baharara et } \\
\text { al. } 2017 \\
{[25]}\end{array}$ \\
\hline & $\begin{array}{l}\text { Cinnamon (bark of } \\
\text { Cinnamomum tree) oil }\end{array}$ & $\begin{array}{l}\text { Albumin denaturation } \\
\text { assay }\end{array}$ & $\begin{array}{l}\text { Concentration-dependent inhibition of } \\
\text { inflammatory activity }\end{array}$ & $\begin{array}{l}\text { Ansari KA } \\
\text { et al. } 2019 \\
{[26]}\end{array}$ \\
\hline & $\begin{array}{l}\text { Saponin (bioactive } \\
\text { compound obtained from } \\
\text { seeds of } \\
\text { Madhucalongifolia) }\end{array}$ & Male Swiss albino mice & Inhibition of inflammation & $\begin{array}{l}\text { Sharma et } \\
\text { al. } 2018 \\
{[27]}\end{array}$ \\
\hline & $\begin{array}{l}\text { Prunus serrulata fresh } \\
\text { fruit extract }\end{array}$ & $\begin{array}{l}\text { Murine macrophages } \\
\text { (RAW264.7) }\end{array}$ & $\begin{array}{l}\text { Anti-inflammatory activity, } \\
\text { downregulation of inflammatory gene } \\
\text { expression }\end{array}$ & $\begin{array}{l}\text { Singh et al. } \\
\text { 2018a [28] }\end{array}$ \\
\hline & $\begin{array}{l}\text { Aqueous gooseberry } \\
\text { extract }\end{array}$ & $\begin{array}{l}\text { Saccharomyces } \\
\text { cerevisiae (yeast) }\end{array}$ & $\begin{array}{l}\text { Histone modifications (downregulation } \\
\text { of histone methylation and upregulation } \\
\text { of histone acetylation) }\end{array}$ & $\begin{array}{l}\text { Babele et } \\
\text { al. } 2019 \\
{[38]}\end{array}$ \\
\hline & $\begin{array}{l}\text { Cynara scolymus leaf } \\
\text { extract }\end{array}$ & $\begin{array}{l}\text { Human breast cancer cell } \\
\text { line MCF- } 7\end{array}$ & $\begin{array}{l}\text { Cytotoxicity, ROS generation, induction } \\
\text { of apoptosis }\end{array}$ & $\begin{array}{l}\text { Erdogan et } \\
\text { al. } 2019 \\
{[31]}\end{array}$ \\
\hline & $\begin{array}{l}\text { Juniperus procera leaf } \\
\text { extract }\end{array}$ & $\begin{array}{l}\text { Splenic cells of adult } \\
\text { male Sprague Dawley } \\
\text { rats }\end{array}$ & $\begin{array}{l}\text { Antibacterial activity against } \\
\text { Micrococcus luteus, Bacillus subtilis, } \\
\text { Proteus mirabilis, and Klebsiella } \\
\text { pneumoniae, antifungal activity against } \\
\text { Candida albicans, proinflammatory } \\
\text { activity, dose-dependent stimulation of } \\
\text { cell growth }\end{array}$ & $\begin{array}{l}\text { Ibrahim et } \\
\text { al. } 2019 \\
{[32]}\end{array}$ \\
\hline & $\begin{array}{l}\text { Nepetadeflersiana } \\
\text { aqueous extract }\end{array}$ & $\begin{array}{l}\text { Human cervical cancer } \\
\text { cell line HeLa }\end{array}$ & $\begin{array}{l}\text { Concentration-dependent cytotoxicity, } \\
\text { ROS generation, lipid peroxidation, } \\
\text { induction of apoptosis }\end{array}$ & $\begin{array}{l}\text { Al-Sheddi } \\
\text { et al. } 2018 \\
\text { [30] }\end{array}$ \\
\hline
\end{tabular}


Table 1 continued

\begin{tabular}{|c|c|c|c|c|}
\hline $\begin{array}{l}\text { Bacterial } \\
\text { nanocellulose/silver } \\
\text { (BNC/Ag) } \\
\text { nanocomposite } \\
\text { films }\end{array}$ & $\begin{array}{l}\text { AgNPs synthesized using } \\
\text { Citrullus colocynthis fruit } \\
\text { extract within BNC RM1 } \\
\text { produced by fermentation } \\
\text { of bacterium } \\
\text { Gluconacetobacter } \\
\text { xylinus }\end{array}$ & \multirow[t]{2}{*}{$\begin{array}{l}\text { Analysis of wound } \\
\text { healing in human dermal } \\
\text { fibroblast cells in vitro }\end{array}$} & \multirow{2}{*}{$\begin{array}{l}\text { Antibacterial activity against } \\
\text { Staphylococcus aureus, S. epidermidis, } \\
\text { and Pseudomonas aeruginosa, and } \\
\text { promotes wound healing through down } \\
\text { regulation of two miRNAs } \\
\text { (has-mir-29-3p and has-mir-29c-3p) } \\
\text { involved in wound healing }\end{array}$} & $\begin{array}{l}\text { Moniri et } \\
\text { al. } 2018 b \\
{[46]}\end{array}$ \\
\hline $\begin{array}{l}\text { Nanocomposite } \\
\text { films }\end{array}$ & $\begin{array}{l}\text { Magnetic NPs }\left(\mathrm{Fe}_{3} \mathrm{O}_{4}\right) \\
\text { prepared using Aloe vera } \\
\text { extract within BNC RM1 } \\
\text { produced by G. xylinus }\end{array}$ & & & $\begin{array}{l}\text { Moniri et } \\
\text { al. 2018a } \\
{[45]}\end{array}$ \\
\hline $\begin{array}{l}\text { Magnetic iron } \\
\text { oxide NPs (MNPs) }\end{array}$ & $\begin{array}{l}\text { Albizia adianthifolia leaf } \\
\text { extract }\end{array}$ & $\begin{array}{l}\text { Human breast cancer cell } \\
\text { lines AMJ-13 and } \\
\text { MCF-7 }\end{array}$ & $\begin{array}{l}\text { Concentration-dependent cytotoxicity, } \\
\text { inhibition of colony formation, } \\
\text { concentration-dependent free radical } \\
\text { scavenging activity, loss of } \\
\text { mitochondrial membrane potential, } \\
\text { induction of apoptosis, DNA damage }\end{array}$ & $\begin{array}{l}\text { Sulaiman et } \\
\text { al. } 2018 \text { [7] }\end{array}$ \\
\hline \multirow[t]{2}{*}{$\begin{array}{l}\text { Platinum NPs } \\
\text { (PtNPs) }\end{array}$} & $\begin{array}{l}\text { Apigenin, a plant-derived } \\
\text { flavonoid }\end{array}$ & $\begin{array}{l}\text { Human peripheral blood } \\
\text { monocytic cell line } \\
\text { THP-1 }\end{array}$ & $\begin{array}{l}\text { Concentration-dependent cytotoxicity, } \\
\text { damage to plasma membrane integrity, } \\
\text { ROS generation, lipid peroxidation, } \\
\text { generation of reactive nitrogen species, } \\
\text { increase in protein carbonylation, } \\
\text { oxidative stress, decrease in expression } \\
\text { of antioxidant markers (GSH, GPX, } \\
\text { GST, GR, CAT, SOD), loss of } \\
\text { mitochondrial membrane potential, } \\
\text { induction of apoptosis, oxidative damage } \\
\text { to DNA and RNA, alteration in } \\
\text { expression of these glycosylases } \\
\text { involved in DNA repair, increase in } \\
\text { expression of proinflammatory cytokines }\end{array}$ & $\begin{array}{l}\text { Gurunathan } \\
\text { et al. } 2019 \\
\text { [8] }\end{array}$ \\
\hline & $\begin{array}{l}\text { Azadirachta indica leaf } \\
\text { extract }\end{array}$ & HEK293 & $\begin{array}{l}\text { Change in cell morphology at high } \\
\text { concentration, ROS generation, loss of } \\
\text { mitochondrial membrane potential, } \\
\text { induction of apoptosis, DNA damage }\end{array}$ & $\begin{array}{l}\text { Almeer et } \\
\text { al. } 2018 \\
{[10]}\end{array}$ \\
\hline \multirow{3}{*}{$\begin{array}{l}\text { Zinc oxide NPs } \\
\text { (ZnONPs) }\end{array}$} & $\begin{array}{l}\text { Bacterial strain } \\
\text { Rhodococcus erythropolis } \\
\text { K85 }\end{array}$ & $\begin{array}{l}\text { Triticum aestivum } \\
\text { (wheat) seedlings }\end{array}$ & $\begin{array}{l}\text { Negative effect on seed germination, } \\
\text { growth-survival rates, other } \\
\text { physiological activities, and modulation } \\
\text { of gene expression levels }\end{array}$ & $\begin{array}{l}\text { Gulluce et } \\
\text { al. } 2020[9]\end{array}$ \\
\hline & $\begin{array}{l}\text { Milky latex from } \\
\text { Calotropis gigantea }\end{array}$ & $\begin{array}{l}\text { Roots of germinating } \\
\text { seeds of Lathyrus sativus }\end{array}$ & $\begin{array}{l}\text { ROS generation, lipid peroxidation, } \\
\text { modulation of activity of oxidative stress } \\
\text { related enzymes (CAT, SOD, GPX, } \\
\text { APX), cell death, }\end{array}$ & $\begin{array}{l}\text { Panda et al. } \\
2017[14]\end{array}$ \\
\hline & $\begin{array}{l}\text { Ferulic acid, a } \\
\text { plant-derived phenolic } \\
\text { phytochemical }\end{array}$ & $\begin{array}{l}\text { Circulating tumor DNA } \\
\text { (ctDNA) }\end{array}$ & $\begin{array}{l}\text { ROS generation, oxidative damage to } \\
\text { DNA }\end{array}$ & $\begin{array}{l}\text { Babu et al. } \\
2015[4]\end{array}$ \\
\hline \multirow{3}{*}{ Gold NPs (AuNPs) } & $\begin{array}{l}\text { Marine extremophile } \\
\text { Pseudoalteromonas sp. } \\
\text { Bac178 }\end{array}$ & $\begin{array}{l}\text { Human fibroblasts and } \\
\text { melanoma cells }\end{array}$ & Cytotoxicity, DNA hypomethylation & $\begin{array}{l}\text { Patil et al. } \\
2019[15]\end{array}$ \\
\hline & $\begin{array}{l}\text { Prunus serrulata fresh } \\
\text { fruit extract }\end{array}$ & $\begin{array}{l}\text { Murine macrophages } \\
\text { (RAW264.7) }\end{array}$ & $\begin{array}{l}\text { Anti-inflammatory activity, } \\
\text { downregulation of inflammatory gene } \\
\text { expression }\end{array}$ & $\begin{array}{l}\text { Singh et al. } \\
\text { 2018a [28] }\end{array}$ \\
\hline & $\begin{array}{l}\text { Euphrasia officinalis leaf } \\
\text { extract }\end{array}$ & $\begin{array}{l}\text { Murine macrophages } \\
\text { (RAW264.7) }\end{array}$ & $\begin{array}{l}\text { Anti-inflammatory activity, reduction in } \\
\text { iNOS expression, decrease in NO } \\
\text { production }\end{array}$ & $\begin{array}{l}\text { Liu et al. } \\
2019[29]\end{array}$ \\
\hline
\end{tabular}




\subsection{Effect on Survival and Proliferation of Cells}

Basic cellular functions and physiological processes like cell proliferation, cell metabolism, and even cell death are affected by NPs. Recent studies have indicated that silver NPs (AgNPs) using aqueous extract of Atropa acuminata leaf exhibited larvicidal activity against $3^{\text {rd }}$ instar larvae of disease carrying vector mosquitoes Anopheles stephensi, Aedes aegypti, and Culex quinquefasciatus, but did not harm a crustacean that feeds on mosquito larvae, Mesocyclops thermocyclopoides [6]. Magnetic iron oxide NPs (MNPs) prepared using Albizia adianthifolia leaf extract showed concentration-dependent cytoxicity against human breast cancer (AMJ-13 and MCF-7) cell lines [7]. Green AgNPs inhibited cervical cancer (HeLa) cell lines, but were not toxic against normal (HEK293) cell lines [6]. Conversely, apigenin-biosynthesized platinum NPs (PtNPs) suppressed human peripheral blood monocytic (THP-1) cell line in a dose-dependent manner [8]. In addition, zinc oxide NPs (ZnONPs) synthesized using the bacterial strain Rhodococcus erythropolis K85 negatively affected seed germination, growth-survival rates, and various other physiological activities, as well as modulated gene expression levels in Triticum aestivum (wheat) seedlings [9]. It is apparent that the purity of NPs used and the cell type also influence these cellular effects.

\subsection{Effect on Cell Morphology}

Green synthesized platinum NPs (PtNPs) are reported to induce alteration in cell morphology. At high concentrations (180 and $360 \mu \mathrm{g} \mathrm{mL}^{-1}$ ), PtNPs synthesized using Azadirachta indica leaf extract changed the shape of human embryonic kidney (HEK293) cells. This change was not observed at lower concentrations [10]. Reduction in cell number and length of cellular protrusions, loss of uniformity, and shrinkage of cell clusters has been observed. At higher concentrations, noticeable membrane blebbing and loss of plasma membrane integrity was seen [8]. Damage to plasma membrane directly leads to cell death. Similar results were obtained with human breast (AMJ-13 and MCF-7) cancer cell lines, where colony formation was inhibited under the influence of biogenic MNPs [7].

\subsection{Reactive Oxygen Species (ROS) Production and Oxidative Stress}

The proportion of ROS generating and ROS scavenging activities affects many cellular processes, and therefore, is tightly regulated within cells. Any imbalance in these levels can lead to oxidative stress. A very prominent effect of entry of NPs into cells is the generation of free radicals, which can have beneficial as well as pathophysiological downstream effects. Overproduction of intracellular ROS and the resulting oxidative stress can lead to cellular damage by lipid peroxidation, as well as molecular damage. Various pathways lead to ROS formation upon entry of NPs into cells, and the significant sites of synthesis of intracellular ROS are mitochondria, endoplasmic reticulum, microsomes, peroxisomes, and seven isoforms of nicotinamide adenine dinucleotide phosphate (NADPH) oxidase (NOX) complexes present in cell membranes. Metal NPs show catalytic behavior, leading to formation of ROS directly on their surface [11]. Incorporation of NPs into cells by phagocytosis also leads to ROS formation. Due to a larger surface area to mass ratio, smaller particles induce more ROS as compared to larger particles, leading to activation of the immune system and inflammatory reactions, by a process very similar to the one that happens during bacterial infections $[12,13]$.

In comparison to $\mathrm{Zn}^{2+}$ ions and chemically synthesized zinc oxide NPs (ZnONPs), lower levels of ROS generation, lipid peroxidation, and cell death were observed in the roots of germinating seeds of Lathyrus sativus, in the presence of ZnONPs synthesized using milky latex from Calotropis gigantea (milkweed) [14]. Significant amount of ROS generation in gamma radiation induced circulating tumor DNA (ctDNA) - green biosynthesized $\mathrm{ZnONP}$ complex was reported in an in vitro experiment, demonstrating the oxidative damage to DNA in the presence of ZnONPs [4]. Green PtNPs induced ROS generation in both concentration- and time-dependent manner [10]. The amount of ROS produced was correlated with ROS-mediated cellular responses such as lipid peroxidation, generation of reactive nitrogen species (nitric oxide [NO], peroxynitrite and nitrous oxide radicals), increase in protein carbonylation, and consequently, cytotoxicity and oxidative stress [8].

\subsection{Effect on Antioxidant Activities}

Antioxidants scavenge free radicals in order to relieve oxidative stress. However, excess production of radicals and oxidative stress leads to inflammation. Thus, it is highly desirable to design NPs that do not induce an immune response while simultaneously regulating cellular metabolism in selective cells, especially for use in the diagnostic and therapeutic fields. In a study, large concentrations (15 to $500 \mu \mathrm{g} \mathrm{mL}^{-1}$ ) of gold NPs (AuNPs) synthesized using a marine extremophile Pseudoalteromonas sp. Bac178 were observed to show reduced toxicity towards both fibroblasts and melanoma cells, whereas chemically synthesized AuNPs were toxic even at low concentration $\left(1 \mu \mathrm{g} \mathrm{mL}^{-1}\right)$. In addition, both normal and cancer cells did not undergo oxidative stress [15]. Biosynthesized MNPs exhibited concentration-dependent free radical scavenging activity in a 2, 2-diphenyl-1-picryl-hydrazyl-hydrate (DPPH) antioxidant assay, most likely due to adherence of functional groups from the Albizia adianthifolia leaf 
extract on the surface of MNPs, during synthesis [7]. Biosynthesized AgNPs also showed notable DPPH, hydrogen peroxide $\left(\mathrm{H}_{2} \mathrm{O}_{2}\right)$, and superoxide $\left(\mathrm{O}_{2}{ }^{-}\right)$radical scavenging activity, effective inhibition of albumin denaturation, and antiprotease activity, suggesting the potential antioxidant and anti-inflammatory role of these NPs [6].

Green NPs are also reported to modify the activity of antioxidant enzymes. Entry of green ZnONPs into cells led to ROS generation, along with a reduction in the activity of catalase (CAT), and a simultaneous increase in the activities of superoxide dismutase (SOD), glutathione peroxidase (GPX) and ascorbate peroxidase (APX) exhibiting a dose-response trend. However, the alteration in activities of these was lower in comparison to the change induced by $\mathrm{Zn}^{2+}$ and chemically synthesized ZnONPs. Even though zinc is an essential micronutrient for plants, the results highlighted that green ZnONPs create oxidative stress, and are phytotoxic [14]. In another study, exposure of human THP-1 cells to $\mathrm{IC}_{50}$ concentration of green PtNPs led to a significant decrease in the expression of antioxidant markers such as glutathione (GSH), GPX, glutathione S-transferase (GST), glutathione reductase (GR), CAT, and SOD [8]. The chemical composition, size, shape, surface area, and concentration of metallic NPs, and other factors such as $\mathrm{pH}$ of the medium, mode of interaction with cells, aggregation, and inflammation, regulate the balance between ROS and antioxidant production in cells. The most important factor is concentration of the NPs, whose low concentration increases the antioxidant levels for combating oxidative stress, while high concentration elicits excess ROS formation, causing inflammation and cell death [16].

\subsection{Effect on Cellular Metabolic Activities}

The electron transport chain in mitochondria is blocked by exposure to NPs, resulting in mitochondrial membrane depolarization and generation of ROS [16]. In several studies, normal as well as cancer human cell lines (AMJ-13, MCF-7, HEK293, THP-1, CHANG, and HuH-7), when subjected to green MNPs [7], PtNPs [8,10], or AgNPs [17], showed loss of mitochondrial membrane potential (MMP), fragmented lysosome membrane, and depleted ATP levels. These reports demonstrate loss in metabolic activity and oxidative damage of cells due to NPs.

\subsection{Induction of Apoptosis}

On disintegration of mitochondrial membrane due to oxidative stress, cytochrome $\mathrm{c}$ is released to the cytosol from the intermembrane space, leading to activation of the apoptotic gene caspase 9 , and subsequently, caspase $3[18$, 19]. Antiapoptotic genes maintain mitochondrial membrane integrity in the cell. Accordingly, loss of mitochondrial function is a predominant biomarker of apoptosis. Two prosurvival proteins, $\mathrm{Bcl} 2$ and its homolog $\mathrm{Bcl}-\mathrm{xl}$, bind to the multidomain proapoptotic proteins Bax and Bak, obstructing the development of pores in the outer membrane of mitochondria, and thus, interfere with the apical proapoptotic signals. Moreover, Bcl-xl binds to the apoptogenic transcription factor $\mathrm{p} 53$, leading to inhibition of the mitochondrial permeability transition [20-22].

Green PtNPs treated HEK293 and THP-1 cells have been reported to show significantly increased expression of apoptotic genes such as p53, p21, Bax, Bac, caspase 9 and caspase 3, and antiapoptotic genes encoding Bcl2 and Bcl-xl exhibited remarkable down regulation $[8,10]$. Similar apoptotic DNA fragmentation was observed in AMJ-13 and MCF-7 cells treated with green MNPs [7]. Hepatic normal (CHANG) and cancer (HuH-7) cells, administered with green AgNPs, also revealed escalated activity of caspase-3 along with increased chromatin condensation. However, the levels were found to be higher in cancer cells in comparison to normal cell lines [17].

\subsection{Oxidative Damage to DNA and RNA}

NPs induced ROS can cause oxidative damage to nucleic acids, through base substitutions, insertions, deletions, or any other deleterious mutations, which can lead to stalled replication forks or chromosome aberrations, and ultimately, cell death. The principal victim of attack by hydroxyl radical $(\bullet \mathrm{OH})$ is guanine, generating the biomarkers of oxidative damage to DNA and RNA, 8-oxo-7, 8-dihydro-2'-deoxyguanosine (8-oxodG) and 8-oxo-7,8-dihydroguanosine (8-oxo G), respectively. 8-oxodG can efficiently pair with adenine or cytosine, leading to trans version mutations [23, 24].

Intercalation of biosynthesized ZnONPs between ctDNA bases has been reported, causing slight destacking of DNA base pairs, unwinding of the double strand, and change from $\mathrm{B}$ to $\mathrm{C}$ conformation [4]. Moreover, fragmented DNA was also detected in AMJ-13 and MCF-7 cells treated with green MNPs [7], in HEK293 cells subjected to green PtNPs [10], and in CHANG and HuH-7 cells exposed to green AgNPs [17]. Significant dose-dependent elevation in levels of 8-oxodG and 8-oxoG, the biomarkers of oxidatively damaged DNA and RNA, respectively, was also noticed in green PtNP treated THP-1 cells [8]. Although the exact molecular mechanism of oxidative damage on exposure to NPs still remains to be deciphered, there are indications that once the lipid membrane is damaged and NPs reach the nucleus, direct interactions may occur between small NPs and nucleic acids.

\subsection{Effect on Regulation of DNA Damage and Repair Genes}

Base excision repair (BER) is predominant among the 
various pathways employed by the cellular machinery to repair DNA lesions such as oxidized DNA bases, single-strand breaks (SSBs), and abasic (AP) sites. Interference with activity of DNA repair proteins hinders the repair process of oxidative damaged DNA. Dose-dependent upregulation of glycosylases involved in BER, such asOGG-1, APEX1, CREB1, POLB, UMG, and GADD45A, was seen in THP-1 cells on exposure to green PtNPs, suggesting alterationin expression of these glycosylases involved in DNA repair [8].

\subsection{Effect on Inflammatory Response}

Subsequent to uptake of NPs, if antioxidants are overwhelmed by excessive ROS generation, inflammation arises. After exposure of THP-1 cells to ultra-small (1-2 $\mathrm{nm})$ green PtNPs, significant concentration-dependent increase in expression levels of proinflammatory cytokines, namely interleukin-1 $\beta$ (IL-1 $\beta$ ), IL-6, IL-8, tumor necrosis factor- $\alpha$ (TNF- $\alpha$ ), granulocyte-macrophage colony-stimulating factor (GM-CSF), and monocyte chemoattractant protein 1 (MCP-1), was reported [8]. These cytokines are known to stimulate differentiation and proliferation of mast cells.

However, anti-inflammatory activity of biosynthesized NPs has been observed in multiple studies. In MCF-7 cells, green AgNPs $(16 \mathrm{~nm})$ coated with sage (Salvia officinalis) leaf extract led to downregulation of IL-8, TNF- $\alpha$, and cyclooxygenase- 2 (COX-2), which causes release of the inflammation promoter prostaglandin E2 (PGE2) and liberation of inflammatory lipids [25]. In the presence of AgNPs prepared using cinnamon (bark of Cinnamomum tree) oil, dose-dependent inhibition of inflammatory activity was detected by an albumin denaturation assay [26]. In an in vivo experiment to assess the anti-inflammatory potential of AgNPs biosynthesized in the presence of the bioactive compound saponin (obtained from seeds of Madhuca longifolia), male Swiss albino mice were injected with carrageenan, subsequent to oral administration of AgNPs,in order to induce acute hind paw edema. There was a pronounced decrease (70.99\%) in inflammation in AgNP treated mice, as compared to the control mice. Histological investigation of intestine of the control group revealed extensive damage to the serosa, muscularis layer, villi tips, and crypts. In contrast, the AgNP treated mice fared much better with more uniform serosa and muscularis layer showing many villi [27]. In another study, AgNPs and AuNPs synthesized using fresh fruit extract of Japanese cherry, Prunus serrulata, exhibited anti-inflammatory activity in murine macrophages (RAW264.7). There was a marked decrease in the amount of PGE2 production and downregulation in expression of inflammatory genes and proteins COX-2 and inducible nitric oxide synthase (iNOS; leads to synthesis of NO). Simultaneous administration of AgNPs and AuNPs led to dose-dependent inhibition of expression of nuclear factor kappa B (NF-kB) p38 and its protein inhibitor (p-IкB), phosphorylated c-Jun-N-terminal kinase (p-JNK), and phosphorylated extracellular signal-related kinase (p-ERK) [28]. p38 mitogen-activated protein kinase (MAPK) signaling pathway leads to phosphorylation of transcription factors for several inflammatory mediators, including NF-kB. $\mathrm{p}-\mathrm{I} \kappa \mathrm{B} \alpha$ remains bound to the NF- $\kappa \mathrm{B}$ dimer in the cytosol in its inactive state. Phosphorylation results in ubiquitination and degradation of $\mathrm{p}-\mathrm{I} \kappa \mathrm{B} \alpha$, concurrent with the nuclear translocation of NF- $\kappa \mathrm{B}$, where it further activates multiple inflammatory genes. Singh et al. (2018a) [28] have postulated that suppression of inflammatory processes has occurred due to hindrance in activation of NF- $\kappa B$. Similar results were obtained in a different study, where AuNPs prepared using Euphrasia officinalis leaf extract were employed to inhibit inflammation in LPS-stimulated RAW264.7 macrophages. There was dose-dependent repression in release of proinflammatory cytokines TNF- $\alpha$, IL-1 $\beta$, and IL-6.Additionally, there was suppression of phosphorylation and degradation of $\mathrm{p}-\mathrm{I} \kappa \mathrm{B} \alpha$, and reduction in levels of nuclear NF- $\kappa \mathrm{B}$. The authors analyzed the Janus kinase/signal transducer and activators of transcription (JAK/STAT) pathway as well, which plays an important role in activating iNOS and elevating NO generation. In the presence of AuNPs, there was dose-dependent down regulation of LPS-stimulated phosphorylation of STAT1, STAT3, and JAK1. Reduction in iNOS expression, along with decrease in NO production, was also detected [29]. Altogether, these reports reveal that green NPs coated with biomolecules may be capable for the treatment of inflammatory disorders. On account of these reasons, green synthesized NPs are increasingly being explored for their anticancer, cytotoxic, and antimicrobial potential [30-32].

\section{Effect on Epigenome}

Although green NPs are coveted for their biomedical utility, their effects on epigenetic regulation are a major concern, especially since these changes are extremely stable, which can be inherited through several generations, and have the potential to be modified under the influence of certain cellular or environmental context. Pogribna \& Hammons [33] studied the effects of exposure to various nanomaterials and nanoparticles on two major epigenetic mechanisms, DNA methylation and histone modifications, and explain the potential role of epigenetic changes in the mechanisms of nanomaterials and nanoparticles toxicity. Some of these epigenetic changes have been summarized below.

\subsection{Alterations in DNA Methylation Pattern}

DNA methylation involves addition of a methyl group 
at the C5 position of cytosine in CpGdinucleotides, in reactions catalyzed by DNA methyltranferases (DNMTs). These $\mathrm{CpG}$ repeats occur at a high frequency in certain regions of the genome called as $\mathrm{CpG}$ islands. In contrast, DNA demethylation can be an active as well as passive process, where thymidine glycosidases some translocator proteins are involved and 5-hydroxymethylcytosine is formed. Hypermethylation in the promoter region is known to silence gene expression, whereas hypomethylation activates gene expression. The DNA methylation pattern is associated with important activities like genomic imprinting, X-chromosome inactivation, DNA repair, maintenance of chromosome stability, continuation of cell cycle, and apoptosis. Alterations in the methylation pattern have been correlated with several human diseases, including cancer.

Changes in the DNA methylation pattern are influenced through various pathways, and one of these is the induction of ROS by NPs in the cell. Global DNA hypomethylation, to the tune of more than $20 \%$, along with change in expression levels of DNMTs, in human epidermal keratinocyte $\mathrm{HaCaT}$ cell line in response to increasing concentrations of $\mathrm{SiO}_{2} \mathrm{NPs}$, was first reported by Gong et al. [34]. Since then, genotoxicity and hypomethylation in response to various NPs have been described in studies conducted in vivo, even in planta [35, 36]. There have been no conclusive studies showing any contrasting results with green NPs, with preliminary studies indicating that they generally induce hypomethylation upon exposure [15]. Further studies are needed in this direction.

\subsection{Effect on Histone Modifications}

Post-translational modifications (PTMs) of the terminal amino tail of histones through methylation, acetylation, or phosphorylation changes the DNA packaging strength. This process, called chromatin remodeling, in turn alters accessibility of the transcription machinery to these regions and affects gene expression. Abnormal regulation of the histone-modifying enzymes leads to abnormal PTMs in histones of cancer cells.

Reduction in hemoglobin levels in erythroleukemia cells of mouse, upon exposure to sublethal concentrations of AgNPs, due to decrease in methylation of H3K4me3 and $\mathrm{H} 3 \mathrm{~K} 79 \mathrm{me}$ 1, has been reported previously. A probable reason is the direct binding of AgNPs to histones $\mathrm{H} 3$ and $\mathrm{H} 4$, leading to the repression of specific histone methyltransferases [37]. On similar lines, Saccharomyces cerevisiae (yeast) cells exhibited significant downregulation of histone methylation (H3K4me2 and H3K36me3), and selective upregulation of histone acetylation (H3K56ac, H4K8ac, and H4K16ac), upon exposure to AgNPs synthesized using aqueous gooseberry extract [38]. Further, these histone modifications can be used as markers to evaluate the toxicity induced by NPs [39].

\subsection{Effect on Non-protein Coding RNA (ncRNA) Expression}

ncRNAs are important components of the epigenetic machinery that modulate gene expression through dynamic interactions with DNA, RNA, and proteins, leading to DNA methylation, histone modifications, and chromatin remodeling. They may be classified as short ( $<200$ nucleotides; miRNAs, endogenous siRNAs, or piRNAs) or long (natural antisense transcripts, long intergenic, or sense intronic) ncRNAs [40].

Conspicuous changes in expression levels of 16 miRNAs in lungs of mice subjected to surface-coated nanotitanium dioxide particles $($ nanoTiO $)$, was the first indication of altered expression of ncRNAs in response to NPs. Lung inflammation was also observed, but no direct connection between modification in miRNA expression and pulmonary injury could be established in this study [41]. Since then, change in expression of miRNAs and cellular toxicity due to exposure to NPs has been widely reported [42-44]. In two studies conducted by the same group, bacterial nanocellulose/silver (BNC/Ag) nanocomposite films were used for in vitro analysis of wound healing. Briefly, AgNPswere biosynthesized using extract from fruits of Citrullus colocynthis within BNC RM1 produced by the fermentation of the bacterium Gluconacetobacter xylinus. Likewise, in a similar study by the same group, nanocomposite films, composed of magnetic NPs $\left(\mathrm{Fe}_{3} \mathrm{O}_{4}\right)$ prepared using Aloe vera extract within BNC RM1 produced by G. xylinus, were synthesized. Significant downregulation in expression of two miRNAs (has-mir-29-3p and has-mir-29c-3p) at varying time intervals was observed. These miRNAs are involved in regulation of epithelial-mesenchymal transition, cellular differentiation, modeling of extracellular matrix, and angiogenesis, through interaction with genes involved in the wound healing process. These reports demonstrate that nanocomposite films can serveasa desirable option for biocompatible wound dressing $[45,46]$.

Taken together, it is apparent that green NPs influence the epigenome, leading to alteration in gene expression. However, extensive studies are needed to understand the molecular mechanisms behind it.

\section{Conclusions}

The literature on green synthesized NPs assure of their benefits in countless spheres, their adverse effects on various cellular processes and epigenetic pathways cannot be ignored. Regarding genotoxicity, the induction of oxidative damage to DNA due to oxidative stress is 
well-documented. This has prompted many authors to refer to NPs as a double-edged sword [23, 47]. Comprehensive research needs to be undertaken to identify the impact of exposure to green NPs, not only on the living system, but also in terms of its environmental impact, which remains a lacuna. With the help of nanotechnology, water quality can be improved. Some of the nanomaterials that can be used for remediation of water are carbon nanotubes (CNTs), zeolites, nanoparticles of zero valent iron (ZVI), silver nanoparticles, etc. Other nanomaterials like zinc oxide $(\mathrm{ZnO})$, titanium dioxide $\left(\mathrm{TiO}_{2}\right)$, tungsten oxide, serve as a photocatalyst [48]. Nanomaterials can be utilized to help with cleaning the climate and even give productive energy solutions, for example, nanomaterial based sun powered cells. Likewise, nanomaterials help to work on the quality and execution of numerous customer items. Another new innovation is known as nanofiltration which can be utilized in water treatment in homes, workplaces, and industries. Molybdenum disulphide (MoS2) nonporous membrane is utilized for energy productive desalination of water which filters five times more than the conventional ones [49]. This is an environmentally friendly technology which is developed and used to conserve natural resources. Studies on NPs also need to establish the shape, size, concentration, composition, and other physical, chemical, or functional properties, prior to their appearance in the clinical or commercial arena. Future research should not be limited to examination of the consequences of NPs exposure in a few cell lines or through the omics approach, but broaden the arena to include different genetic backgrounds and multiple arrays of exposure conditions.

\section{REFERENCES}

[1] J. Singh, T. Dutta, K. H. Kim, M. Rawat, P. Samddar, and P. Kumar, "Green' synthesis of metals and their oxide nanoparticles: applications for environmental remediation," Journal of nanobiotechnology, vol. 16, no. 1, pp. 84, 2018b, DOI: $10.1186 / \mathrm{s} 12951-018-0408-4$

[2] E. R. Balasooriya, C. D. Jayasinghe, U. A. Jayawardena, R. W. D. Ruwanthika, R. Mendis de Silva, and P. V. Udagama, "Honey mediated green synthesis of nanoparticles: new era of safe nanotechnology," Journal of Nanomaterials, 2017, DOI: $10.1155 / 2017 / 5919836$

[3] N. Noah, "Green synthesis: Characterization and application of silver and gold nanoparticles," In Green Synthesis, Characterization and Applications of Nanoparticles, Elsevier, pp. 111-135, 2019, DOI: 10.1016/B978-0-08-102579-6.00006-X.

[4] E. P. Babu, A. Subastri, A. Suyavaran, P. L. Rao, M. S. Kumar, K. Jeevaratnam, and C. Thirunavukkarasu, "Extracellularly synthesized $\mathrm{ZnO}$ nanoparticles interact with DNA and augment gamma radiation induced DNA damage through reactive oxygen species," RSC Advances, vol. 5, no. 76, pp. 62067-62077, 2015, DOI: $10.1039 / \mathrm{C} 5 \mathrm{RA} 09935 \mathrm{H}$.

[5] P. Foroozandeh, and A. A. Aziz, "Insight into cellular uptake and intracellular trafficking of nanoparticles," Nanoscale research letters, vol. 13, no. 1, pp. 339, 2018, DOI: $10.1186 / \mathrm{s} 11671-018-2728-6$.

[6] S. Rajput, D. Kumar, and V. Agrawal, "Green synthesis of silver nanoparticles using Indian Belladonna extract and their potential antioxidant, anti-inflammatory, anticancer and larvicidal activities," Plant Cell Reports, 2020, DOI: 10.1007/s00299-020-02539-7.

[7] G. M. Sulaiman, A. T. Tawfeeq, and A. S. Naji, "Biosynthesis, characterization of magnetic iron oxide nanoparticles and evaluations of the cytotoxicity and DNA damage of human breast carcinoma cell lines," Artificial cells, nanomedicine, and biotechnology, vol. 46, no. 6, pp. 1215-1229, 2018, DOI: 10.1080/21691401.

[8] S. Gurunathan, M. Jeyaraj, M. H. Kang, and J. H. Kim, "The Effects of Apigenin-Biosynthesized Ultra-Small Platinum Nanoparticles on the Human Monocytic THP-1 Cell Line," Cells, vol. 8, no. 5, pp. 444, 2019, DOI: 10.3390/cells 8050444

[9] M. Gulluce, M. Karaday, A. Y. Demir, C. Işık, B. Alaylar, and N. H. Ispirli, "Genotoxic Potentials of Biosynthesized Zinc Oxide Nanoparticles," Polish Journal of Environmental Studies, vol. 29, no. 1, 2020, DOI: $10.15244 /$ pjoes/99239.

[10] R. S. Almeer, D. Ali, S. Alarifi, S. Alkahtani, and M. Almansour, "Green platinum nanoparticles interaction with HEK293 cells: Cellular toxicity, apoptosis, and genetic damage," Dose-Response, vol. 16, no. 4, 2018, DOI: $10.1177 / 1559325818807382$

[11] N. Narayan, A. Meiyazhagan, and R. Vajtai, "Metal Nanoparticles as Green Catalysts," Materials, vol. 12, no. 21, pp. 3602, 2019, DOI: 10.3390/ma12213602.

[12] D. M. Brown, K. Donaldson, and V. Stone, "Effects of PM 10 in human peripheral blood monocytes and J774 macrophages.," Respiratory research, vol. 5, no. 1, pp.29, 2004, DOI: 10.1186/1465-9921-5-29

[13] H. Long, T. Shi, P. J. Borm, J. Maatta, K. Husgafvel-Pursiainen, K. Savolainen, and F. Krombach, "ROS-mediated TNF- $\alpha$ and MIP-2 gene expression in alveolar macrophages exposed to pine dust," Particle and fibre toxicology, vol. 1, no. 1, pp. 3, 2004, DOI: $10.1186 / 1743-8977-1-3$

[14] K. K. Panda, D. Golari, A. Venugopal, V. M. M. Achary, G. Phaomei, N. L. Parinandi, H. K. Sahu, and B. B. Panda, "Green synthesized zinc oxide $(\mathrm{ZnO})$ nanoparticles induce oxidative stress and DNA damage in Lathyrus sativus L. root bioassay system," Antioxidants, vol. 6, no. 2, pp. 35, 2017, DOI: 10.3390/antiox6020035

[15] Y. M. Patil, S. N. Rajpathak, and D. D. Deobagkar, "Characterization and DNA methylation modulatory activity of gold nanoparticles synthesized by Pseudoalteromonas strain," Journal of biosciences, vol. 44, no. 1 , pp. 15, 2019, DOI: 10.1007/s12038-018-9842-6

[16] A. Nel, T. Xia, L. Madler, and N. Li, "Toxic potential of materials at the nanolevel," Science, vol. 311, no. 5761, pp. 
622-627, 2006, DOI:10.1126/science. 1114397

[17] M. Bin-Jumah, A. A. Monera, G. Albasher, and S. Alarifi, "Effects of Green Silver Nanoparticles on Apoptosis and Oxidative Stress in Normal and Cancerous Human Hepatic Cells in vitro," International Journal of Nanomedicine, vol. 15, pp.1537, 2020, DOI: 10.2147/IJN.S239861.

[18] P. Li, D. Nijhawan, I. Budihardjo, S. M. Srinivasula, M. Ahmad, E. S. Alnemri, and X. Wang, "Cytochrome c and dATP-dependent formation of Apaf-1/caspase-9 complex initiates an apoptotic protease cascade," Cell, vol. 91, no. 4, pp. 479-489, 1997, DOI: 10.1016/S0092-8674(00)80434-1.

[19] S. M. Srinivasula, M. Ahmad, T. Fernandes-Alnemri, and E. S. Alnemri, "Autoactivation of procaspase-9 by Apaf-1-mediated oligomerization," Molecular cell, vol. 1, no. 7, pp. 949-957, 1998, DOI: 10.1016/S1097-2765(00)80095-7.

[20] D. M. Finucane, E. Bossy-Wetzel, N. J. Waterhouse, T. G. Cotter, and D. R. Green, "Bax-induced caspase activation and apoptosis via cytochromec release from mitochondria is inhibitable by Bcl-xL," Journal of Biological Chemistry, vol. 274, no. 4, pp. 2225-2233, 1999, DOI: 10.1074/jbc.274.4.2225.

[21] J. Michels, O. Kepp, L. Senovilla, D. Lissa, M. Castedo, G. Kroemer, and L. Galluzzi, "Functions of BCL-XL at the interface between cell death and metabolism," International journal of cell biology, 2013, DOI:10.1155/2013/705294

[22] Z. N. Oltval, C. L. Milliman, and S. J. Korsmeyer, "Bcl-2 heterodimerizes in vivo with a conserved homolog, Bax, that accelerates programed cell death," Cell, vol. 74, no. 4, pp. 609-619, 1993, DOI: 10.1016/0092-8674(93)90509-o.

[23] M. Carriere, S. Sauvaigo, T. Douki, and J. L. Ravanat, "Impact of nanoparticles on DNA repair processes: current knowledge and working hypotheses," Mutagenesis, vol. 32, no. 1, pp, 203-213, 2017, DOI:10.1093/mutage/gew052.

[24] C. Guo, P. Ding, C. Xie, C. Ye, M. Ye, C. Pan, X. Cao, S. Zhang, and S. Zheng, "Potential application of the oxidative nucleic acid damage biomarkers in detection of diseases," Oncotarget, vol. 8, no. 43, pp.75767, 2017, DOI:10.18632/oncotarget.20801.

[25] J. Baharara, T. Ramezani, M. Mousavi, and M. Asadi-Samani, "Antioxidant and anti-inflammatory activity of green synthesized silver nanoparticles using Salvia officinalis extract," Annals of Tropical Medicine and Public Health,vol. 10, no. 5, pp.1265-1270, 2017 , DOI:10.4103/ATMPH.ATMPH_174_17.

[26] M. T. Ansari KA, A. Roy, and S. Rajeshkumar, "Anti-inflammatory activity of cinnamon oil mediated silver nanoparticles-An in vitro study," International Journal of Research in Pharmaceutical Sciences, vol. 10, no. 4, pp. 2970-2972, 2019, DOI: 10.26452/ijrps.v10i4.1579.

[27] M. Sharma, S. Yadav, M. Srivastava, N. Ganesh, and S. Srivastava, "Promising anti-inflammatory bio-efficacy of saponin loaded silver nanoparticles prepared from the plant Madhuca longifolia," Asian Journal of Nanosciences and Materials, vol. 1, no. 4. pp. 244-261, 2018, DOI:10.26655/AJNANOMAT.2018.9.5.

[28] P. Singh, S. Ahn, J. P. Kang, S. Veronika, Y. Huo, H. Singh, M. Chokkaligam, M. E. A. Farh, V. C. Aceituno, Y. J. Kim, and D. C Yang, "In vitro anti-inflammatory activity of spherical silver nanoparticles and monodisperse hexagonal gold nanoparticles by fruit extract of Prunus serrulata: a green synthetic approach," Artificial cells, nanomedicine, and biotechnology, vol. 46, no. 8, pp. 2022-2032, 2018a, DOI: $10.1080 / 21691401$.

[29] Y. Liu, S. Kim, Y. J. Kim, H. Perumalsamy, S. Lee, E. Hwang, and T. H. Yi, "Green synthesis of gold nanoparticles using Euphrasia officinalis leaf extract to inhibit lipopolysaccharide-induced inflammation through NF- $\kappa$ B and JAK/STAT pathways in RAW 264.7 macrophages," International journal of nanomedicine, vol. 14, pp. 2945-2959, 2019, DOI: 10.2147/IJN.S199781.

[30] E. S. Al-Sheddi, N. N. Farshori, M. M. Al-Oqail, S. M. Al-Massarani, Q. Saquib, R. Wahab, J. Musarrat, A. A. Al-Khedhairy, and M. A. Siddiqui, "Anticancer potential of green synthesized silver nanoparticles using extract of Nepetadeflersiana against human cervical cancer cells (HeLA)," Bioinorganic Chemistry and Applications, 2018, DOI: $10.1155 / 2018 / 9390784$

[31] O. Erdogan, M. Abbak, G. M. Demirbolat, F. Birtekocak, M. Aksel, S. Pasa, and O. Cevik, "Green synthesis of silver nanoparticles via Cynara scolymus leaf extracts: The characterization, anticancer potential with photodynamic therapy in MCF7 cells," PloS one, vol. 14, no. 6, 2019, DOI: 10.1371/journal.pone.0216496.

[32] E. H. Ibrahim, M. Kilany, H. A. Ghramh, K. A. Khan, and S. ul Islam, "Cellular proliferation/cytotoxicity and antimicrobial potentials of green synthesized silver nanoparticles (AgNPs) using Juniperus procera," Saudi journal of biological sciences, vol. 26, no. 7, pp. 1689-1694, 2019, DOI: 10.1016/j.sjbs.2018.08.014.

[33] M. Pogribna, G. Hammons, "Epigenetic Effects of Nanomaterials and Nanoparticles," J Nanobiotechnol., vol. 19, no.2, 2021, DOI: 10.1186/s12951-020-00740-0.

[34] C. Gong, G. Tao, L. Yang, J. Liu, Q. Liu, and Z. Zhuang, "SiO2 nanoparticles induce global genomic hypomethylation in $\mathrm{HaCaT}$ cells," Biochemical and biophysical research communications, vol. 397, no. 3, pp. 397-400, 2010, DOI: 10.1016/j.bbrc.2010.05.076.

[35] T. A. Brown, J. W. Lee, A. Holian, V. Porter, H. Fredriksen, M. Kim, and Y. H. Cho, "Alterations in DNA methylation corresponding with lung inflammation and as a biomarker for disease development after MWCNT exposure," Nanotoxicology, vol. 10, no. 4, pp. 453-461, 2016, DOI:10.3109/17435390.2015.1078852.

[36] I. Ghosh, A. Sadhu, Y. Moriyasu, M. Bandyopadhyay, and A. Mukherjee, "Manganese oxide nanoparticles induce genotoxicity and DNA hypomethylation in the moss Physcomitrella patens," Mutation Research/Genetic Toxicology and Environmental Mutagenesis, vol. 842, pp. 146-157, 2019, DOI: 10.1016/j.mrgentox.2018.12.006.

[37] Y. Qian, J. Zhang, Q. Hu, M. Xu, Y. Chen, G. Hu, M. Zhao, and S. Liu, "Silver nanoparticle-induced hemoglobin decrease involves alteration of histone 3 methylation status.," Biomaterials, vol. 70, pp. 12-22, 2015, DOI: 10.1016/j.biomaterials.2015.08.015.

[38] P. K. Babele, A. K. Singh, and A. Shrivastava, "Bio-inspired silver nanoparticles impose metabolic and epigenetic toxicity to Saccharomyces cerevisiae," Frontiers 
in Pharmacology, vol. 10, pp 1016, 2019, DOI: 10.3389/fphar.2019.01016.

[39] X. Zhao, and Y. Ibuki, "Evaluating the toxicity of silver nanoparticles by detecting phosphorylation of histone $\mathrm{H} 3$ in combination with flow cytometry side-scattered light," Environmental science \& technology, vol. 49, no. 8, pp. 5003-5012, 2015, DOI: 10.1021/acs.est.5b00542.

[40] V. J. Peschansky, and C. Wahlestedt, "Non-coding RNAs as direct and indirect modulators of epigenetic regulation," Epigenetics, vol. 9, no. 1, pp. 3-12, 2014, DOI: 10.4161/epi.27473.

[41] S. Halappanavar, P. Jackson, A. Williams, K. A. Jensen, K. S. Hougaard, U. Vogel, C. L. Yauk, and H. Wallin, "Pulmonary response to surface - coated nanotitanium dioxide particles includes induction of acute phase response genes, inflammatory cascades, and changes in microRNAs: A toxicogenomic study," Environmental and molecular mutagenesis, vol. 52, no. 6, pp. 425-439, 2011, DOI: 10.1002/em.20639.

[42] H. J. Eom, N. Chatterjee, J. Lee, and J. Choi, "Integrated mRNA and micro RNA profiling reveals epigenetic mechanism of differential sensitivity of Jurkat $\mathrm{T}$ cells to AgNPs and Ag ions," Toxicology letters, vol. 229, no. 1, pp. 311-318, 2014, DOI: 10.1016/j.toxlet.2014.05.019.

[43] T. Nagano, K, Higashisaka, A. Kunieda, Y. Iwahara, K. Tanaka, K. Nagano, Y. Abe, H. Kamada, S. Tsunoda, H. Nabeshi, T. Yoshikawa, Y. Yoshioka, and Y. Tsutsumi, "Liver-specific microRNAs as biomarkers of nanomaterial-induced liver damage," Nanotechnology, vol. 24, no. 40, pp. 405102, 2013, DOI: $10.1088 / 0957-4484 / 24 / 40 / 405102$

[44] C. T. Ng, S. T. Dheen, W. C. G. Yip, C. N. Ong, B. H. Bay, and L. Y. L. Yung, "The induction of epigenetic regulation of PROS1 gene in lung fibroblasts by gold nanoparticles and implications for potential lung injury," Biomaterials, vol. 32, no. 30, pp. 7609-7615, 2011, DOI: 10.1016/j.biomaterials.2011.06.038.

[45] M. Moniri, A. B. Moghaddam, S. Azizi, R. A. Rahim, W. Z. Saad, M. Navaderi, P. Arulselvan, and R. Mohamad, "Molecular study of wound healing after using biosynthesized $\mathrm{BNC} / \mathrm{Fe} 3 \mathrm{O} 4$ nanocomposites assisted with a bioinformatics approach," International journal of nanomedicine, vol. 13, pp. 2955-2971, 2018a, DOI: 10.2147//IJN.S159637.

[46] M. Moniri, A. B. Moghaddam, S. Azizi, R. A. Rahim, S. W. Zuhainis, M. Navaderi, and R. Mohamad, "In vitro molecular study of wound healing using biosynthesized bacteria nanocellulose/silver nanocomposite assisted by bioinformatics databases," International journal of nanomedicine, vol. 13, pp. 5097-5112, 2018b, DOI: 0.2147/IJN.S164573.

[47] J. Mytych, and M. Wnuk, "Nanoparticle technology as a double-edged sword: cytotoxic, genotoxic and epigenetic effects on living cells." J Biomater Nanobiotechnol., vol. 4, pp. 53-63, 2013, DOI: 10.4236/jbnb.2013.41008.

[48] I. S. Yunus, Harwin, A. Kurniawan, D. Adityawarman and A. Indarto, "Nanotechnologies in water and air pollution treatment." Environmental Technology Reviews, vol. 1, no. 1, pp. 136-148, 2012, DOI: 10.1080/21622515.2012.73396 6

[49] Z. Yang, Y.Zhou, Z. Feng, X. Rui, T. Zhang, Z. Zhang, “A Review on Reverse Osmosis and Nanofiltration Membranes for Water Purification.” Polymers, vol. 11, pp. 1252, 2019. https://doi.org/10.3390/polym11081252 